DOI 10.37882/2223-2982.2020.09.38

\title{
ЭКСТРАЛИНГВИСТИЧЕСКИЕ ФАКТОРЫ ТРАНСФОРМАЦИИ ПРОФЕССИОНАЛЬНОЙ РЕЧИ ПЕДАГОГОВ
}

\section{EXTRALINGVISTIC FACTORS OF PROFESSIONAL PEDAGOGICS SPEECH TRANSFORMATION}

\section{K. Shipilova}

Summary: Nowadays there is a thorny issue in Russian education system of efficiency of pedagogic performance. This problem is connected to modernisation of education system in general, but also due to need for review of teaching personnel most professional skills. Emphasis must be laid upon professional pedagogue communication as process of organisation of cooperative teachers and students interaction.

In this article it sought to reveal signs of professional pedagogic speech transformation, which could occur due to destructive impact of social and phycological factors. Experimental study was carried out with complex use of phycological surveys, associative tests and part analyse.

Keywords: pedagogue communication, professional language, speech performance, professional pedagogics speech, linguistic consciousness.
Шипилова Кристина Витальевна Аспирант, ГАОУ ВО МГПУ, г. Москва Krista_94@mail.ru

Аннотация: В настоящее время в системе российского образования приобретает остроту вопрос результативности педагогической деятельности учителя. Это связано не только с модернизацией образования в целом, но и пересмотром требований к профессионально-важным качествам педагогических кадров. Особое внимание уделяется профессиональному общению педагогов - процессу, направленному на организацию совместной деятельности ученика и учителя.

В данной статье предпринята попытка выявить признаки трансформации педагогической речи, возникших под деструктивным воздействием ряда социальных и психологических факторов. Экспериментальный материал получен при комплексном использовании психологических тестов, ассоциативного эксперимента и частотного анализа.

Ключевые слова: педагогическое общение, профессиональный язык, речевая деятельность, профессиональная речь педагогов, языковое сознание.

вание факторов и признаков трансформации педагогической речи в сложившихся условиях выступает актуальной задачей психолингвистики.

В психологии педагогический труд классифицируют как профессию с повышенными коммуникативными нагрузками. С.П. Безносов анализирует механизмы трансформации сознания при профессиональной деформации личности. С.П. Безносов утверждает, что деформация личности - это процесс и результат влияния субъектных качеств человека, сформированных в соответствии со спецификой определенного профессионального труда, на личностные свойства целостной индивидуальности работника - профессионала.

Психологическим механизмом деформации, по С.П. Безносову, выступает рассогласование норм человека как субъекта профессиональной деятельности с его личностными нормами и свойствами в конкретной жизненной ситуации. Систематический неадекватный перенос норм профессиональной деятельности в сферу личностного, бытового взаимодействия приводит к негативным изменениям личности человека, его сознания [Безносов 2004]. Специфика педагогического общения усиливает не только коммуникативную, но и эмоциональную нагрузку на педагогическую речь учителя [Бладыко 2012].

Профессиональная деформация личности - измене- 
ние качеств личности, которые наступают под влиянием длительного выполнения профессиональной деятельности. Вследствие неразрывного единства сознания и специфической деятельности формируется профессиональный тип личности. Самое большое влияние профессиональная деформация оказывает на личностные особенности представителей тех профессий, работа которых связана с людьми (педагоги).

Таким образом, можно обобщено сформулировать следующий тезис: профессиональная деформация личности проявляется в изменении качеств личности, которые наступают под влиянием длительного выполнение деятельности, а также при работе в стрессовых условиях.

Р. Конечный и М. Боухал считают, что склонность к профессиональной деформации наблюдается у профессии педагога, «представители которых обладают трудно контролируемой и трудно ограничиваемой властью» [см. Ермолаева 2000]. Профессиональная деформация постепенно развивается из профессиональной адаптации. Именно профессия преподавателя как нельзя лучше отражает структуру и динамику профессиональной деформации.
По Э.Ф. Зееру профессиональные деформации определяются как накопившиеся изменения сложившейся структуры деятельности и личности что, по его мнению, отрицательно сказывается на взаимодействии с другими участниками данного процесса и эффективности труда, а также отражается на развитии личности.

Следовательно, профессиональная деформация личности педагога может выступать деструктивным психологическим фактором, приводящим к трансформации его профессиональной речи. Учитывая тот факт, что общение организует совместную деятельность [Тарасов 2004; Мыскин 2015, 2018], можно предположить, что трансформированная педагогическая речь обусловливает неэффективные формы взаимодействия ученика и учителя.

Опираясь на структуру и динамику профессиональной деформации личности Э.Ф. Зеера, нами было проведено пилотное исследование речевых сообщений педагогов с различными проявлениями профессиональной деформации личности. Ниже приведены примеры некоторых из них (таблица 1).

Таблица 1

Анализ речевых сообщений педагогов с различными проявлениями профессиональной деформации личности

\begin{tabular}{|c|c|c|}
\hline Проявление деформации & Психологическое содержание понятия & Сопутствующие речевые сообщения учителя \\
\hline Авторитарность & $\begin{array}{l}\text { Авторитарность педагога проявляется в централизации } \\
\text { всего учебно-воспитательного процесса, единоличном осу- } \\
\text { ществлении управленческих функций, использовании пре- } \\
\text { имущественно распоряжений, рекомендаций, указаний. } \\
\text { Авторитарность обнаруживается в снижении рефлексии } \\
\text { - самоанализа и самоконтроля педагога. }\end{array}$ & $\begin{array}{l}\text { «Иванов, не крутись!», «Иванов, не вертись!», «Иванов, } \\
\text { положи руки на место!», «Иванов, сколько можно повто- } \\
\text { рять!». }\end{array}$ \\
\hline Доминантность & $\begin{array}{l}\text { Обусловлена выполнением педагогом властных функ- } \\
\text { ций. Ему даны большие права: требовать, наказывать, } \\
\text { оценивать, контролировать. Доминантность почти у всех } \\
\text { педагогов со стажем работы более } 10 \text { лет. }\end{array}$ & $\begin{array}{l}\text { «Не разговаривать - поставлю двойки». } \\
\text { «ты еще будешь со мной пререкаться? Выйди вон». } \\
\text { «Не надо никого слушать! Слушайте только меня!» }\end{array}$ \\
\hline $\begin{array}{l}\text { Педагогическая (речевая) } \\
\text { агрессия }\end{array}$ & $\begin{array}{l}\text { Агрессия проявляется в речи учителей: пренебрежительно- } \\
\text { грубое или повелительно-покровительственное отношение } \\
\text { к ученикам проявляется в повышении тона, резких воскли- } \\
\text { цаниях, неоправданно частом употреблении повелитель- } \\
\text { ного наклонения глаголов, отсутствии необходимых фор- } \\
\text { мул речевого этикета, грубых замечаниях и язвительных } \\
\text { насмешках. } \\
\text { Речевую агрессию в самом общем виде можно определить, } \\
\text { как словесное выражение негативных эмоций, намерений } \\
\text { в оскорбительной, грубой форме. }\end{array}$ & $\begin{array}{l}\text { «Ну все!», «Вы меня достали!», «Закрыли все рты!»», } \\
\text { «Будешь так себя вести, кдиректору/завучу отведу», «Вы- } \\
\text { брошу твой телефон, если еше достанешь», } \\
\text { «Вы что, больные что ли!» } \\
\text { «Вы можете дальше продолжать играть:я поставлю еди- } \\
\text { нищы!», } \\
\text { «Я в детском саду или в школе?», } \\
\text { «0, явилось, красное солнышко! Выспался?», } \\
\text { «Где тетрадь? } \\
\text { - Забыла... } \\
\text { - А голову ты не забыла?», } \\
\text { «Утебя в голове опилки, а должны быть знания». }\end{array}$ \\
\hline Сверхконтроль & $\begin{array}{l}\text { Выражается в чрезмерном сдерживании своих чувств, } \\
\text { ориентации на инструкции, уходе от ответственности, по- } \\
\text { дозрительной осмотрительности, скрупулезном контроле } \\
\text { деятельности учеников. }\end{array}$ & $\begin{array}{l}\text { «Вы сюда не думать пришли, делайте, как говорят», } \\
\text { «здесь правила устанавливаю я» (без объяснений). }\end{array}$ \\
\hline
\end{tabular}


Авторитарные педагоги демонстрируют речевое взаимодействие, ограниченное лишь учебно-предметной сферой. У таких учителей более постоянный и более узкий круг учащихся, с которыми они вступают в контакты, их сообщения учащимся бедны по форме и содержанию.

Педагогу необходимо затрачивать больше личностных и энергетических ресурсов для обеспечения целостности речи, ее адекватного фонетического оформления, выдержки логики построения, структурированности и последовательности речевых продуктов (текстов). Эмоциональная, наряду с когнитивной, составляющая выполняет одну из ведущих ролей при производстве речи [Жинкин 1958]. Эмоциональные нагрузки способствуют к увеличению неосознаваемых ассоциативных связей, что со временем меняет соотношение рационального и иррационального в профессиональном мышлении учителя в пользу последнего [Петренко 2005: 163]. Некритическое решение педагогом профессиональных познавательных задач делает его педагогическую речь не только неэффективной, но и безадресной. Профессиональная картина мира учителя искажается [Карданова 2010; Черкашина 2012 и др.].

В своей работе А.А. Леонтьев говорил, что педагогическое общение - специфическое межличностное взаимодействие педагога и обучающегося, опосредующее усвоение знаний и становление личности в учебно-воспитательном процессе. Часто педагогическое общение определяется как взаимодействие субъектов педагогического процесса, осуществляемое знаковыми средствами и направленное на значимые изменения свойств, состояний, поведения и личностно-смысловых образований партнеров. Как видно, педагогическое общение неотъемлемый элемент профессиональной деятельности учителя; вне его невозможно достижение целей обучения и воспитания [Леонтьев 1996].

Дальнейшее психолингвистическое исследование особенностей профессиональной речи педагогов будет осуществляться с опорой на обоснованные и признанные научным сообществом концепции, подходы и теории следующих авторов: С.П. Безносова, Л.Г. Викуловой, Н.И. Жинкина, А.А. Леонтьева, С.В. Мыскина, Е.Ф. Тарасова и др.

В данном анализе мы следуем установке, постулирующей необходимость для учителя соблюдения в своей работе социальных и речевых норм. Педагог должен возвращаться в нормативное русло вне зависимости от спонтанного развития коммуникативных ситуаций, он должен реализовывать нормативное общение [Викулова 2008].

В основной части нашего исследования было изучено профанное сознание педагогов на предмет выявле- ния их представлений о значимых характеристиках эффективной педагогической речи.

В экспериментальном исследовании участвовали 4 группы преподавателей из ГАОУ ВО МГПУ «Институт среднего профессионального образования имени К.Д. Ушинского» г. Москвы. Первую и вторую группы соответственно составили 40 преподавателей и 45 учителей, находящихся в состоянии стресса. В третью и четвертую группу соответственно вошли 50 преподавателей и 50 учителей, находящихся в состоянии психологической «нормы».

Трудовой стаж в образовательных учреждениях каждого преподавателя и учителя составлял не менее трех лет.

На первом этапе основного эксперимента посредством психологического тестирования была выявлена степень профессионального выгорания педагогов всех групп. Результаты психологического тестирования позволили разделить педагогов на две группы. Экспериментальная группа - педагоги с высоким уровнем психологического выгорания. Контрольная группа педагоги с отсутствием признаков профессионального выгорания.

На втором этапе основного эксперимента было исследовано языковое сознание участников при помощи ассоциативного эксперимента. Педагогам было предложено дань несколько направленных реакций на стимул «эффективная педагогическая речь». Обработка результатов ассоциативного эксперимента позволила определить профанные представления педагогов о значимых характеристиках педагогической речи. Ниже приведены результаты.

По мнению преподавателей основными факторами успешного освоения учебного материала учениками являются грамотная речь и простота, ясность изложения - 85\% респондентов приводят данные характеристики в своих ответах. При этом абсолютное большинство опрошенных указывают подобные показатели в первую очередь. Также, ключевыми критериями профессиональной речи среди педагогов являются: выразительность и эмочиональность речи - 78\%, содержательность - 71\%, логичность - 64\%, а также учет возрастных особенностей воспринимающего - 63\%. Далее стоит обратить внимание на однородность полученных эмпирических данных по результатам опроса. Так, более половины респондентов (57\%) относят к значимым характеристикам точность, образность, интонацию и тональность речи. Половина опрошенных учителей также считают важными факторами убедительность, уместность применяемых примеров, четкость, чистоту и темп речи. Следует отме- 
тить, что «профессионально выгоревшие» педагоги не отмечали в своих ответах психологические признаки профессиональной речи, например, ориентация на потребности ученика, его психолого-возрастные особенности.

На третьем этапе основного эксперимента запланирован анализ речевого поведения педагогов в стрессогенных коммуникативных педагогических ситуациях. Данное исследование позволит выявить неадекватное смысловое употребление педагогами профессиональных терминов. В качестве диагностического материала разработана анкета-опросник, направленная на выявление неадекватных речевых шаблонов (клише) при педагогическом общении (при речевом воздействии на учеников). Результаты, полученные на данном этапе исследования, позволят выявить неадекватное смеще- ние семантических полей педагогических терминов, возникающее под влиянием деструктивных эмоциональных состояний педагога.

Таким образом, можно сформулировать следующие выводы:

- трансформация педагогической речи под деструктивным воздействием социальных и психологических факторов проявляется в нивелировании психологических структурных аспектов речевых сообщений педагогов ученикам, которые в совокупности составляют содержание педагогического общения (по А.А. Леонтьеву);

- профессиональное выгорание оказывает деструктивное воздействие на речевые сообщения педагога, и является экстралингвистическим фактором трансформации его профессиональной речи.

\section{ЛИТЕРАТУРА}

1. Безносов С.П. Профессиональная деформация личности / С.П. Безносов. - СПб: Речь, 2004. - 272 с.

2. Бладыко А.В. Особенности эмоционального выгорания у учителей и преподавателей / А.В. Бладыко // Психология: традиции и инновации: матер. Междунар. науч. конф. (г. Уфа, октябрь 2012 г.) / отв. ред. 0.А. Шульга. - Уфа: Лето, 2012. - С. 34-39.

3. Борытко Н.М. Методология и методы психолого-педагогического исследования: учеб.пособие для студ.высш.учеб.заведений / Н.М. Борытко, А.В. Моложавенко, И.А. Соловцова; под ред. Н.М. Борытко. - 2-е изд.,стер. - М.: Издательский центр «Академия», 2009. - 320 с.

4. Ермолаева М.В. Психология развития: Методическое пособие для студентов заочной и дистанционной форм обучения. / М. В. Ермолаева - М.: Московский психолого - социальный институт; Воронеж: Изд. НПО «МОДЭК», 2000. - 336 с.

5. Жинкин Н.И. Механизмы речи / Н.И. Жинкин. - М.: Изд-во Акад. пед. наук РСФСР, 1958. - 370 с.

6. Карданова К.С. Языковая картина мира: мифы и реальность / К.С. Карданова // Русский язык в школе. 2010. № 9- С. 61-66.

7. Леонтьев А.А. Педагогическое общение: брошюра / А.А. Леонтьев. - М.-Н.: Эль-Фа, 1996. - 92 с.

8. Мыскин С.В. Психолингвистические аспекты профессионального общения / С.В. Мыскин // Вестник волгоградского государственного университета. Сер.: Языкознание. - 2013. - № 2 (18). - С. 199-206.

9. Мыскин С.В. Теоретико-методологические аспекты теории языковой профессиональной личности / С.В. Мыскин // Вестник РУдН. Сер.: Теория языка. Семиотика. Семантика. М., 2015. - № 1. - С. 62-75.

10. Мыскин С.В. Организационно-психологический анализ профессионального сознания работников современных трудовых коллективов // Организационная психолингвистика. М.: 000 «Агентство социально-гуманитарных технологий», 2018. № 1(1). С. 2. С. 21-38.

11. Петренко В.Ф. К проблеме построения образа мира: психосемантический аспект / В.Ф. Петренко // Общение. Языковое сознание. Межкультурная коммуникация. Сб. статей/ Институт языкознания РАН. Калуга: КГПУ им. К.Э. Циолковского, 2005. С. 155-177.

12. Тарасов Е.Ф. Проблемы теории речевого общения // Вопросы психолингвистики. 2010. № 2(12). С. 20-26.

13. Тарасов Е.Ф. Языковое сознание / Е.Ф. Тарасов // Вопросы психолингвистики. - 2004. - № 2. - С. 34-47.

14. Черкашина Е.И. Современные тенденции профессиональной подготовки преподавателя иностранного языка / Е.И. Черкашина // Вестник Томского государственного педагогического университета. 2012. № 5 (120). - С. 58-64.

15. Delacroix H. Le langage et la pensee. Paris: F.Alcan, 1930. 624 p.

16. Kainz F. Psychologie der Sprache, Bd. I. Stuttgart, 1941, S. 22.

17. Laguna G.A. de. Speech: its function and development, 2nd ed., Bloomington, 1953, p. IX. 